\title{
A Stepwise Approach of Factors Affecting Agricultural Production in Nigeria
}

\author{
Anietie Edem Udokang \\ Statistics Department, Federal Polytechnic, Offa, Kwara State, Nigeria \\ Email address: \\ anietieeu@yahoo.com \\ To cite this article: \\ Anietie Edem Udokang. A Stepwise Approach of Factors Affecting Agricultural Production in Nigeria. Science Journal of Business and \\ Management. Vol. 8, No. 3, 2020, pp. 149-153. doi: 10.11648/j.sjbm.20200803.17
}

Received: July 22, 2015; Accepted: September 26, 2015; Published: September 17, 2020

\begin{abstract}
This paper is to study area harvested, number of people employed and quantity of fertilizer used as factors that affect agricultural crop production in Nigeria. The best variable selection/stepwise method is used to determine the factor(s) that contributed more to crop production in Nigeria. The factors were the explanatory variables and crop production was the response variable. Steps were taken to be able to identify the individual factors contribution to the crop production and possibly the combination of factors contribution to crop production. This is in order to determine the factor(s) to give more attention to increase crop production for lucrative investment in agriculture and food security. The analysis revealed that area of land harvested contributed most significantly to crop output (production) in Nigeria in overall comparison to fertilizer and number of people employed. The area of land harvested and number of people employed as one set of factors that influence crop production gives higher effect on crop production than using another set of factors as area of land harvested and quantity of fertilizer. The models with the two sets of factors were not significant leading to the fact that the major contributor to crop production in Nigeria is area of land harvested. This is pointing to the fact that the labour force is enough to transform the agricultural crop production sector in Nigeria if more land is acquired for agriculture with an improved technology. The stakeholders in agricultural sector in Nigeria are to expand the harvested land especially when the country has not developed to the extent of full agricultural mechanization.
\end{abstract}

Keywords: Crop Production, Stepwise, Agriculture, Variable, Economy

\section{Introduction}

Nigeria is the largest producer of crude oil in Africa and about 10th largest producer in the world, and her economy has solely depends on revenue from crude oil export without much attention to other sectors like agriculture. The country is blessed with the vast land, good weather, good soil and so on for crop production. The country is depending heavily on food importation instead of being food sufficient. According to the Minister of Agriculture and Rural Development, Dr Akinwumi Adesina at his inaugural meeting with official of the Ministry of Agriculture, said that the government in 2010 imported wheat worth 635 billion Naira, spent 356 billion Naira on importation of rice, 217 billion Naira on sugar, and 97 billion Naira on fish. The food import bill of Nigeria in 2007-2010 was 97trillion naira or 628 billion dollars [1].

Based on this fact, crop production in Nigeria is one of the ways out of over dependent on importation. This paper will determine the factors that government need to put more effort on increasing food production. A country that is not food sufficient or secured is very far away from vision 20:20:20. Therefore, agricultural sector has to be transformed.

The importation should not be as it is because Nigeria has potential to feed its citizens and even export to other countries. The problem had always been the issue of implementation as government lip service to agricultural development instead of utilizing the potential of having agriculture friendly weather, natural resources like land, water, oil and so on, which can be rated number one in Africa [2].

\section{Agriculture and Nigeria Economy}

Nigerian economy has its root from agriculture before and 
after independent. Its contribution to the national economy was tremendous before full oil exploration in the Niger Delta (South South Region) of Nigeria. Gone are the days when agriculture contributed more than $50 \%$ of Gross Domestic Product (GDP) and more than $75 \%$ of export earnings before independent. Thereafter, the popular groundnut pyramid in the North and cocoa in the South West region of the country. Nigeria major source of income was mostly from agriculture, the economy was buoyant, the currency was strong and unemployment not as high as it is now. Many academicians and researchers from different part of the world visited Nigeria because of its agricultural potentials. One of them was an agricultural expert from Israel who visited Nigeria in 2005. It was from his findings that he concluded in a press briefing that Nigeria is blessed with good land, weather and everything needed to boost agriculture.

The country depends on crude oil which contributed to a substantial part of the national economy. The analysis of oil revenue in 2014 showed that oil revenue (gross) was 6,793.8 billion Naira, representing 67.5 per cent of revenue [5]. The revenue from oil should be diversified to agriculture because if well harnessed can be a good source of provision of jobs for millions of youth who are unemployed. For instance, in Kwara the State Government through the appropriate agencies has given land and farm inputs to the beneficiaries and the farm produce bought by the government. The government has also signed a contract with the white farmers from Zimbabwe to encourage mechanized farming and expanded the agreement to 13 white farmers' families. The government and the commercial farmers union from Zimbabwe in July, 2004 signed a collaborative agreement on agriculture. In pursuance of this the government undertook to grant leasehold of agricultural land of approximately of 1000 hectares to each of the 13 farmers. These efforts will help in reducing unemployment and current food crisis experience in Nigeria and indeed the world.

Federal government because of the important of agriculture has established many agriculture related research institutes like Nigerian Stored Product Research Institute (NISPRI), Agricultural Research and Management Institute (ARMTI) and National Centre for Agricultural Mechanization (NCAM).

The point is if the money accrued from oil is properly diversified to agriculture the nation can regain its past glory. More attention will be given to the storage of farm produce to reduce waste, make foodstuff available at all times of the year and also have for export to regain our position at international market [6]. This can be a major contribution to our foreign reserves and provide raw materials for local industries.

Agriculture in Nigeria is commonly done at peasant level, even though there are some large scale farming. It is a common practice that families who are not farmers go into backyard or small scale farming at subsistence level. Hence, agriculture in Nigeria is characterized by small holder farmers $(0.05$ to 3.0 ha per farm land) scattered over wide expanse of land area, multiple rudimentary cropping systems, low capitalization and low yield per hectare [7].
A research carried out on agricultural production and economic growth in Nigeria with focus on poverty alleviation showed an indication that agricultural production was a significant factor that influenced the favourable trend of economic growth in Nigeria [8].

\section{A Review of Crop Production in Nigeria}

In other to improve crop production in Nigeria many research institutes has been established as earlier mentioned. These research institutes were established to complements the efforts of the Federal Ministry of Agriculture in improving the quantity and quality of agricultural produce in Nigeria through a more efficient process with local content. This notwithstanding, Individuals at local levels has tried methods to improve production. In some instances, the methods cannot scientifically proven like yam festivals which are organized before consumption of the first sets of yam harvested believing to boost yam production in subsequent years.

A study carried out on the trend of crop production in Nigeria and how to improve the quantity of food produced in relation to rapid increase in population growth. The study used regression model and made the following discoveries; that the physical output of food crops in Nigeria portrayed a clear trend over the period reviewed. Out of all the crops studied, cassava constituted $62.27 \%$ of the total output of the crops within the period under review, followed by maize $(14.3 \%)$, and then millet $(11.96 \%)$; rice was $6.54 \%$. the lowest contribution of $4.92 \%$ came from beans [9]. This portrayed the fact that cassava production is easiest of all the crops mentioned above in which the government can use such advantage to have more than enough cassava for consumption in Nigeria. It is also true that cassava is consumed in different varieties as fufu, garri, flour, boiled and so on.

Nigeria has not been able to attend food sufficiency through crop production, except before independent and thereabout when Nigeria had food surplus of about $70 \%$ [10]. The food insufficiency was estimated to be over $40 \%$ of the country's population which is due to lack of mechanization and the small scale nature of production [11].

There are challenges that marred crop production but the solution are use of modern planting materials with good breeding programme that enable the emergence of indigenous seed firms with commercial orientation, the use of integrated pest management procedures, the use of the right production system and mechanization strategies of research and development based on local conditions and not mere importations based on alien conditions and agroforestry [10].

The efficiency of the farmers is another factor in crop production in Nigeria from the onset till presently. The productive efficiency of farmers for most crops fell below $60 \%$ despite all human and material resources devoted to Nigerian agriculture. Presently, the efficiency has not been 
achieved which led to the rejection of some of the exported crops [12-14]. Factors such as accurate use of low input technologies, relative use of high input technologies, inadequate knowledge of farm management skills, poor implementation extension services, unavailability and high cost of inputs contributed negatively to crop production.

In other to determine factors that affect domestic agricultural production in Nigeria a study was carried out on the growth in the various agricultural sub sectors of the Nigerian economy between1981-2003. The annual growth rate of the domestic agricultural production was calculated and six variables were identified. The variables are; real value of agricultural production as dependent (response) variable while Food import values, GDP growth rate, Population Growth Rate, Consumer Price Index and Government Expenditure on Agriculture were independent (explanatory) variables. There was no appreciative growth rate and the independent variables contributed positively to agricultural production except food import values. The study however did not pay attention to some factors that directly affected the cultivation, planting and harvesting of crops [15].

The technical efficiency and the influence of some socioeconomic characteristics of farmers on productivity was also examined using stochastic frontier production function. The study revealed that the variances of parameters of the frontier production function were statistically significant at 1 percent level of significance. The study also revealed that there was positive relationship between farm size, seed, fertilizer, hired labour, family labour and herbicides [16].

Agricultural production in Nigeria using principles of location relation to market, the principle of comparative advantage and von Thune's classical theory on land use showed that agricultural production of cereals and pulses are determined by natural factors and nearness to market. Also, oil seeds production are determined and sustained by both natural factors and nearness to market. While tree crops production are determined by natural factors, internal migrations, agricultural innovation diffusion and existence of marketing board [17].

Another study considered is on the effect of agroclimate factors on the yield of cash crops in Nigeria using mainly error-correction model (ECM) within the context of cointegration theory. It was discovered that producer price, temperature and GDP were the most significant factors that influenced the yield of cocoa while only exchange rate was the most significant factor that influenced palm produce [18].

This paper will consider variables, some not mentioned above, to study and identify factor(s) that contributed directly to crop production in Nigeria. Based on this the three factors (independent variables) are area of land harvested, number of people employed and quantity of fertilizer used to determine the order of significant effects of factors on crop production/output in Nigeria.

\subsection{Source of Data}

The data used for this paper is from the National Bureau of Statistics, Annual Abstract of Statistics 2008, produced under the auspices of Federal Government Economic Reform And Governance Project (ERGP). The data considered is from $2002 / 2003$ to $2006 / 2007$.

\subsection{Presentation of Data}

Table 1. Crop Production (Major Crops) with the Factors.

\begin{tabular}{llll}
\hline Year/ Season & $\begin{array}{l}\text { Cultivated / Area } \\
\text { Harvested (000'ha) }\end{array}$ & $\begin{array}{l}\text { No Employed } \\
\text { (000'Employee) }\end{array}$ & $\begin{array}{l}\text { Quantity of Fertiliser } \\
\text { Used (00'Kg) }\end{array}$ \\
\hline $2002 / 2003$ & 22737.11 & 16368 & 50623.00 \\
$2003 / 2004$ & 22275.44 & 16368 & 63261.87 \\
$2004 / 2005$ & 22530.28 & 16420 & 73482.49 \\
$2005 / 2006$ & 24930.15 & 16420 & 71664.91 \\
$2006 / 2007$ & 25097.00 & 15875 & 76089.54 \\
\hline
\end{tabular}

The area harvested, the number employed, quantity of fertilizer used and crop output show a steady increase in each of the farming seasons between 2002/2003 to 2006/2007.

\subsection{The Stepwise Regression}

The method of analyzing the data collected for this paper is the stepwise regression analysis in order to determine the variables (factors) that contributed significantly to crop production output (response variable). The stepwise regression analysis is an improvement of the forward selection procedure because it re-examine at every stage of the regression analysis of the variable introduced into the model in previous stages. This is to make sure that the variable that was the best previously is being determined whether it is still useful or not to the model with the introduction of other variables.

The partial $F$ criterion for each variable in the regression at any stage of calculation is evaluated and compared with a pre-selected percentage point of the appropriate $\mathrm{F}$ distribution. This provides a judgment on the contribution made by each variable as though it has been the most recent variable entered irrespective of its actual point of entry in the model. Any variable which provides a non-significant contribution is removed from the model [19].

The stepwise regression procedures are as stated below:

Step I: Compute the simple correlation of the independent variable $X_{k}$ with response variable $Y$ and select the independent variable that is highly correlated with the response variable. This is equivalent to the one with the 
largest Fratio.

Step II: Test for the significant of the selected variable in the model. If it is significant then proceed to Step III.

Step III: Compute the partial correlation of the variable not selected with response variable given that the selected variable is in the model and select the one with the largest partial correlation. This is the same thing as computing the partial $F$ ratio and selecting the variable that has the largest partial $F$ ratio value.

Step IV: Test for significance of the model.

Step V: Test for the significance of each of the variable in the model.

Step VI: The process is repeated till when no variable can be removed and the best variable cannot be significant.

\subsection{Analysis of Data}

Let $X_{1}=$ be area of land harvested

$X_{2}=$ number of people employed in crop production

$X_{3}=$ quantity of fertiliser used.

$Y=$ output of crop production

Step I:

$$
\begin{aligned}
& \hat{y}=\hat{b}_{0}+\hat{b}_{1} x_{1}: F_{\text {ratio }}=15.04 \\
& \stackrel{\Lambda}{y}=\stackrel{A}{b_{0}}+\hat{b}_{2} x_{2}: F_{\text {ratio }}=5.77 \\
& \hat{y}=\stackrel{\Lambda}{b_{0}+b_{3}} x_{3} F_{\text {ratio }}=3.44
\end{aligned}
$$

$X_{1}$ is selected because it has the largest Fratio.

The model is $y=b_{0}+b_{1} x_{1}+e_{i}$

Step II: Test for $X_{1}$ is conducted to either drop or retain it in the model

$$
\hat{y}=\hat{b}_{0}+\hat{b}_{1} x_{1}: F_{\text {ratio }}=15.04(p-\text { value }=0.030)
$$

The model is significant at $5 \%$ level of significant, hence $\hat{b}_{1}=5.706291(\mathrm{p}$-value $=0.030)$ is significant at $5 \%$ level of significant, meaning that $X_{1}$ is retained.

Step III:

$$
\begin{aligned}
& \hat{y}=\stackrel{\Lambda}{b_{0}}+\stackrel{\Lambda}{b_{1}} x_{1}+\stackrel{\Lambda}{b_{2}} x_{2}: F_{2 / 1}=4.48 \\
& \hat{y}=\stackrel{A}{b_{0}}+\stackrel{A}{b_{1}} x_{1}+\hat{b}_{3} x_{3}: F_{3 / 1}=0.08
\end{aligned}
$$

$X_{2}$ is selected as the next variable because it has the largest partial Fratio an indication that the combination of area of land harvested and number of people employed gives higher crop production than the combination of area of land harvested and quantity of fertilizer.

The model is $y=b_{0}+b_{1} x_{1}+b_{2} x_{2}+e$

Step IV:

$$
\hat{y}=\stackrel{A}{b_{0}}+\hat{b}_{1} x_{1}+\hat{b}_{2} x_{2} F_{\text {ratio }}=18.48(p-\text { value }=0.051)
$$

The model is not significant at $5 \%$ level of significant.

Further test shows that none of the variables is significant in the model, note that $X_{1}$ was significant in the earlier model but not significant in the current model because of the relationship between $X_{1}$ and $X_{2}$.

Therefore, the first estimated model in step I is finally considered with the model as $y=b_{0}+b_{1} x_{1}+e$. Meaning that the area of land harvested contributed most significantly to crop production in Nigeria

\section{Conclusions}

The crop output depends mostly on land area harvested with the highest Fratio in the model of crop output depending on land harvested which was significant and having 0.83 coefficient of determination.

The model of crop output as depending on land area harvested and number of people employed even though selected but was not significant but has a high coefficient of variate $\left(R^{2}=0.95\right)$. This might be so because a higher part of the variation is from the land harvested which made the $p$ value very close to the level of significant. This can be partly due to the relationship between area harvested and number of people employed.

Nigeria is blessed with good soil and weather for agriculture that does not require much fertiliser to boost crop production. Also, the labour force in crop farming is enough to transform the agricultural (crop production) sector because of new technology. All what Nigeria need mostly is to expand the area of land harvested with improved technology.

\section{Recommendations}

Base on the findings from the analysis conducted, the government both at federal, states and local councils should motivate the farmers to cultivate more land. This can be done through loans and training of existing farmers.

The federal government should provide subsidy in terms of protecting the farmers from losses, for instance, if there is low harvest or disaster, the government should compensate the farmers to act against fear of the future.

The farmers should avail themselves of modern techniques of farming to have more yields with the same labour.

The entrepreneurship education in tertiary institutions should inculcates modern farming into their curriculum so as to have more effective and efficient farmers in future.

\section{References}

[1] Olugbenga (2011)." Nigeria Spends 99.2 Trillion on Food Importation". The Nations Newspapers, Tuesday, July, 2011. P. 11.

[2] Monde S. (2011). Nigeria has the Potential to Feed its Citizens and Others. Nigerian Tribune, Tuesday, 15 March, 2011. P. 15.

[3] Central Bank of Nigeria Annual Economic Report (2014). The Demostic Economy. ISSN 1597-2976, 1v, pp. 55. 
[4] Uodakang, A. E. (2009). Analysis of Effect of Treated and Control of Farm Produce: A Case Study of Maize. Nigerian Journal of Science and Technical Research (Nijoster), School of Applied Science And Technology, Federal Polytechnic, Offa, Kwara State, Nigeria. Vol. 3 No. 2, 2009.

[5] Amujoyegbe B. J. and Elemo K. A. (2012). Decline in Crop Productivity in Nigeria: A Review of Possible Strategies for Self Reliance, increase And Sustained Production. Journal of Agriculture and Biological Sciences Vol. 3 (1) pp. 250-256.

[6] Oyakhilomen, O. and Zibah, R. G. (2014). Agricultural Production and Economic Growth in Nigeria: Implication for Rural Poverty Alleviation. Quarterly Journal of International Agriculture. Vol. 53, No. 3, 207-223.

[7] Ayandiji, A. and Akintola, J. O. (2009). Trend analysis of food crops production in Nigeria (1990-2005). Journal of Agriculture, Forestry and the Social Sciences. Vol 7, No 2.

[8] Asiegbu, J. E. (2000). Journal of Agriculture, Forestry and the Social Sciences. The challenges of crop production in Nigeria for the 21 st century. Vol 1, No 1.

[9] Mariya-Dixton B, Akinleye E, Oguntona S, Nokoe R, Sanus A, Hariss E. (2004). Nigeria Food Consumption and Nutrition Survey (2001-2003 Summary). International Institute for Tropical Agriculture. (IITA), Ibadan.

[10] Federal Agricultural Coordinating Unit (FACU). Proceeding on the 4th Annual National Farming Systems. Research and
Extension Workshop. Federal Agricultural Coordinating Unit Reports, Ibadan; 1992.

[11] Federal Department of Agriculture (FDA). Food Security and Nigeria Agriculture, Water Resources and Rural Development. Federal Department of Agriculture, Abuja, Nigeria; 1993.

[12] Federal Department of Agriculture (FDA). Federal Department of Agriculture; Federal Ministry of Agriculture Reports. Abuja, Nigeria; 1995.

[13] Muhammad-Lawal A and Atte O. A. (2006). An Analysis of Agricultural Production in Nigeria. African Journal of General Agriculture. Vol. 2, No. 1, June 30.

[14] Taphee, G. B. and Jongur, A. A. U. (2014). Productivity and Efficiency of Groundnut Farming in Nothern Taraba State, Nigeria. Juornal of Agriculture and Sustainability. Volume 5, Number 1, 45-56.

[15] Igwe, C. F. (2015). Observation on the Spatial Patterns of Adricultural Production in Nigeria. Journal of Biology, Agriculture and Healthcare. Vol. 5, No. 10.

[16] Akintunde, O. K., Okoruwa, V. O. and Adeoti, A. I. (2013). The Effect of Agroclimatic Factors on Cash Crops Production in Nigeria. Journal of Central European Agriculture. Vol. 14, No. 13.

[17] Draper D. P. and Smith (1996). Selecting the "Best" Regression Equation. John Wiley and Sons Inc. New York. 